\title{
駅舎トイレを対象とした雨水利用システムに関する研究 A STUDY ON THE RAINWATER USAGE SYSTEM FOR RAILWAY STATION TOILET
}

\author{
越川康夫*, 村川三郎** \\ Yasuo KOSHIKAWA and Saburo MURAKAWA
}

\begin{abstract}
The execution of rainwater utilization system was examined for station toilets with the many user numbers per instrument. The following were set on the past investigation value and Tokyo JR 5 stations using opened data: Precipitation, rainwater collection plane, toilet water consumption and rainwater tank. Afterwards, the usefulness of rainwater utilization system was examined by the simulation. Though as the result, the effect of the rain water tank installation is accepted, the toilet water consumption for one day is large, the range of $136 \mathrm{~m}^{3}$ from $55 \mathrm{~m}^{3}$. Hence, it seems to be the difficulty that the space for the even one day tank is newly installed in the station premise. Moreover, by the simulation method, it was shown to be sufficiently effective for station toilets by the system with the capacity for the maximum water consumption per one hour, using the rainwater without storing that almost.
\end{abstract}

Keywords: : Rainwater usage system, Toilet of railway station, Toilet users, Fixture users, Simulation Water consumption

雨水利用システム, 駅舎トイレ, トイレ利用者, 器具使用者数, シミュレーション, 使用水量

\section{1. 序}

雨水利用に関する研究は, 雨水の水質・水量 ${ }^{122)}$ および副次的な効 果 ${ }^{3)}$ に関するものが多くみられ,これらに基づく検討事例によって， 大型建築物の大規模システムから一般住宅の小規模システムまで, 数多くの雨水利用の㥶施例 ${ }^{4)}$ が報告されている。したがって, 既に省 資源的なシステムとして定着してきている観はあるものの，いまだ に，雨水利用システムの普及率は低く，多くの建物で採用されるに はいたっていないのが現状と考える。

都市部で普及しているトイレの雨水利用システムは, 蒸留水とも いえる良質な雨水を飲用に供している離島の事例 ${ }^{5)}$ を考えれば, その 水質レベルに応じた利用をしているとはいえないが，大気污染の進 んでいる都会では雨水利用の適当な選択肢と考えられる。したがっ て, 水質面からは, 雨水利用普及の妨げになっている要因は考えに くいといえよう。一方, 水量面からみれば, 多数の人々が利用し, 便器あたりの使用頻度および洗浄水量が多大と考えられ，雨水利用 による節水効果が期待される駅舎をはじめとする交通機関建築物の トイレに雨水利用が採用された例はみられなく，雨水の有効利用を 進める上での検討課題として残されている。

そこで, 本研究は, 東京都内の東日本鉄道 5 駅のトイレを対象に, 雨水利用システムの基本条件となる, 収集 (降水量, 雨水収集面積), 貯留 (雨水貯留槽容量), 使用 (トイレ使用水量)を, 既往の調査値お よび降水量デー夕を用いて設定後, 各駅トイレの雨水利用をシミュ レートし，その結果により，駅舎トイレにおける雨水利用の有効性 およびその問題点を水量の面から検討および考察し，適切な雨水利
用システムの提言を行なうことを目的としている。以下では東日本 鉄道を「JR」と略称する。

\section{2. 検討対象駅の概要}

表- 1 に検討対象 5 駅の概要, 表- 2 に各駅の調査対象トイレの器 具数を示す。トイレ利用の調査法および駅の構内図は既報 ${ }^{677}$ ?) ているので省略する。調查対象の T, J 駅は, 都内環状線の巨大夕 一ミナル駅で JR の駅としては最大級の規模を有する。K駅は都内の 放射線に位置し, 近くに大学と住宅地があり，学生と日中の主婦の 利用が多い。S，U駅は都内環状線に位置する。S 駅は若者を対象 とした店舖が多い大規模な商業地区にある。U駅は J R 長距離列車 の終着駅であり，近くに美術館，博物館，公園等がある。

\section{表- 1 検討対象駅 5 駅の概要}

\begin{tabular}{|c|c|c|c|c|c|c|}
\hline 項 & 目 & $\mathrm{T}$ 駅 & $\mathrm{J}$ 駅 & K駅 & $\mathrm{S}$ 駅 & U駅 \\
\hline \multicolumn{2}{|c|}{ 乗降人員（万人/日） } & 101 & 86 & 25 & 58 & 48 \\
\hline \multirow[t]{2}{*}{ 改札口 } & 新幹線 口 & 2 & - & - & - & 1 \\
\hline & 在来線 口 & 12 & 8 & 3 & 4 & 4 \\
\hline \multirow[t]{4}{*}{ 接続線 } & 新幹 線 & 2 & - & - & - & 1 \\
\hline & $\mathrm{J} \mathrm{R}$ 線 & 8 & 4 & 1 & 2 & 6 \\
\hline & 私鉄 $($ 除 <JR) & - & 3 & 1 & 3 & 1 \\
\hline & 地下 鉄 & 1 & 2 & - & 2 & 2 \\
\hline
\end{tabular}

表-2 5 駅調査対象トイレの器具数 (個)

\begin{tabular}{c|rrrrr}
\hline 器具種類 & $\mathrm{T}$ 駅 & $\mathrm{J}$ 駅 & $\mathrm{K}$ 駅 & $\mathrm{S}$ 駅 & $\mathrm{U}$ 駅 \\
\hline 男子大便器 & 6 & 6 & 6 & 6 & 4 \\
男子小便器 & 13 & 12 & 11 & 11 & 18 \\
男子洗面器 & 4 & 4 & 4 & 3 & 4 \\
女子便器 & 10 & 7 & 6 & 7 & 6 \\
女子洗面器 & 7 & 8 & 5 & 3 & 6 \\
\hline
\end{tabular}

*広島大学工学部 助手

**広島大学工学部 教授・工博
Research Assoc., Faculty of Engineering, Hiroshima Univ. Prof., Faculty of Engineering, Hiroshima Univ., Dr. Eng. 


\begin{tabular}{cccc} 
竧- 3 & \multicolumn{4}{c}{ 年降水量 $(\mathrm{mm} /$ 年) } \\
\hline 年 & 東京 & 練馬 & 世田谷 \\
\hline 1987 & 1088 & 1228 & 1143 \\
1988 & 1516 & 1559 & 1679 \\
1989 & 1936 & 1911 & 1964 \\
1990 & 1512 & 1558 & 1636 \\
1991 & 2042 & 2015 & 2105 \\
1992 & 1621 & 1529 & 1738 \\
1993 & 1872 & 1796 & 1917 \\
1994 & 1146 & 1127 & 1266 \\
1995 & 1220 & 1314 & 1412 \\
1996 & 1333 & 1325 & 1480 \\
\hline 平均值 & 1529 & 1536 & 1634 \\
\hline
\end{tabular}

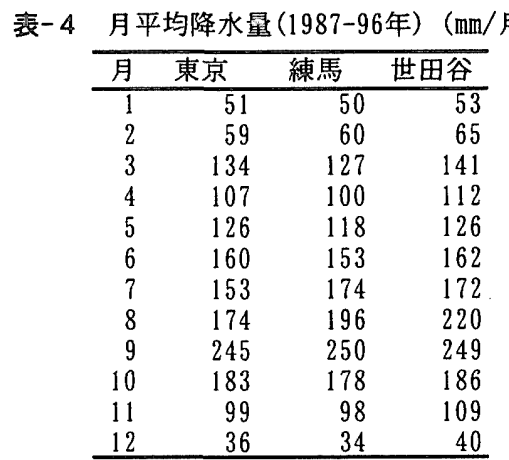

表-5 各曜日の日平均降水量

\begin{tabular}{|c|c|c|c|}
\hline 曜日 & 東京 & 練馬 & 世田谷 \\
\hline 日 & 4.08 & 4.27 & 4.76 \\
\hline 月 & 4.09 & 4.11 & 4.43 \\
\hline 火 & 4.39 & 4.33 & 4.35 \\
\hline 水 & 4.15 & 4.13 & 4.73 \\
\hline 木 & 4.09 & 4.26 & 4.18 \\
\hline 金 & 4.25 & 4.12 & 4.48 \\
\hline 土 & 4.25 & 4.21 & 4.38 \\
\hline
\end{tabular}

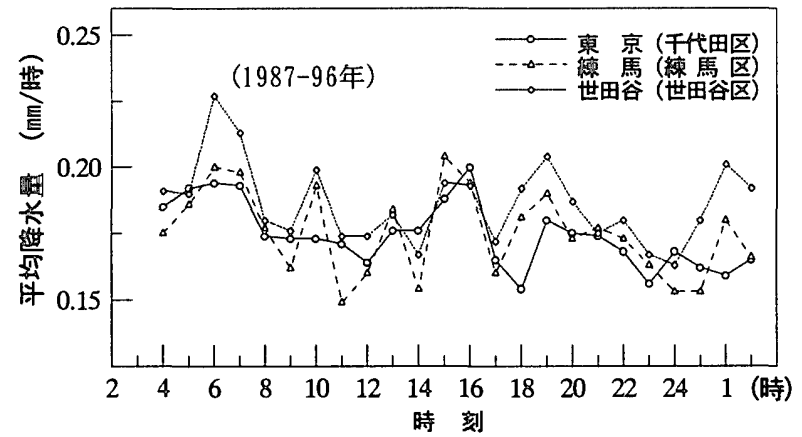

图-1 時間帯別時間平均降水量

\section{3. 駅舎トイレ雨水利用システムの条仵設定}

上述の 5 駅のトイレを対象に，収集(降水量，雨水収集面積），使 用 (トイレ使用水量) および貯留 (雨水貯留槽容量)に関する雨水利用 シミュレーションの基本条件を設定する。

\section{1 降水墨}

雨水利用の検討に必要な降水量は，対象駅に近い観測地点の 1987 年から 10 年分の 1 時間ごとのデータを, 気象庁監修のアメダス観測 年報 CDROM 版より複写し結合して，後述する雨水利用シミュレーシ ヨンに用いる。K駅には練馬観測点，ほかの 4 駅には東京観測点 (千 代田区)のデータを用いた。2 観測点の欠測デー夕は相互に補完した が，2観測点の同一時刻に欠測がある場合には，世田谷観測点のデ 一夕を用いて補完した。世田谷観測点のデータも同様に補完した。 3 観測点データの全てが欠測した時間帯はなかった。

表- $3 \sim 5$ ，図- 1 に 3 観測点の降水量の年, 月, 日, 時の 10 年間 の統計值を示す。表，図より，同じ都内でも降水量に差があり，周 辺が商業地区の東京・練馬観測点に比べて，住宅地区である世田谷 観測点の降水量が多くなっているが，3 観測点の降水量の増減傾向 はおおむね一致していることがわかる。

\section{2 雨水収集面}

駅舎において効率的な雨水収集を考えると，列車の運行および鳥 の飛来により，鉄衯および鳥の粪に污染される可能性もあるが，プ ラットホームの屋根の利用は容易であると考え, プラットホームの 屋根を中心とした雨水収集を想定した。 5 駅のうち，J 駅，U駅の 対象トイレはプラットホームより階上にあるため, トイレが所在す る駅舎の屋上を雨水収集面に含めた。 5 駅のプラットホームおよび 駅舎の状海を図- 2 に示す。図中に雨水収集に利用可能と考えられる プラットホーム屋根面を網かけし，屋上を白く表示した。番号の部 分および「屋上」は，面積を読み取った個所である。読み取った屋 根面積を表- 6 に示す。表の「ホームNo」は, 図-2の番号と同じで
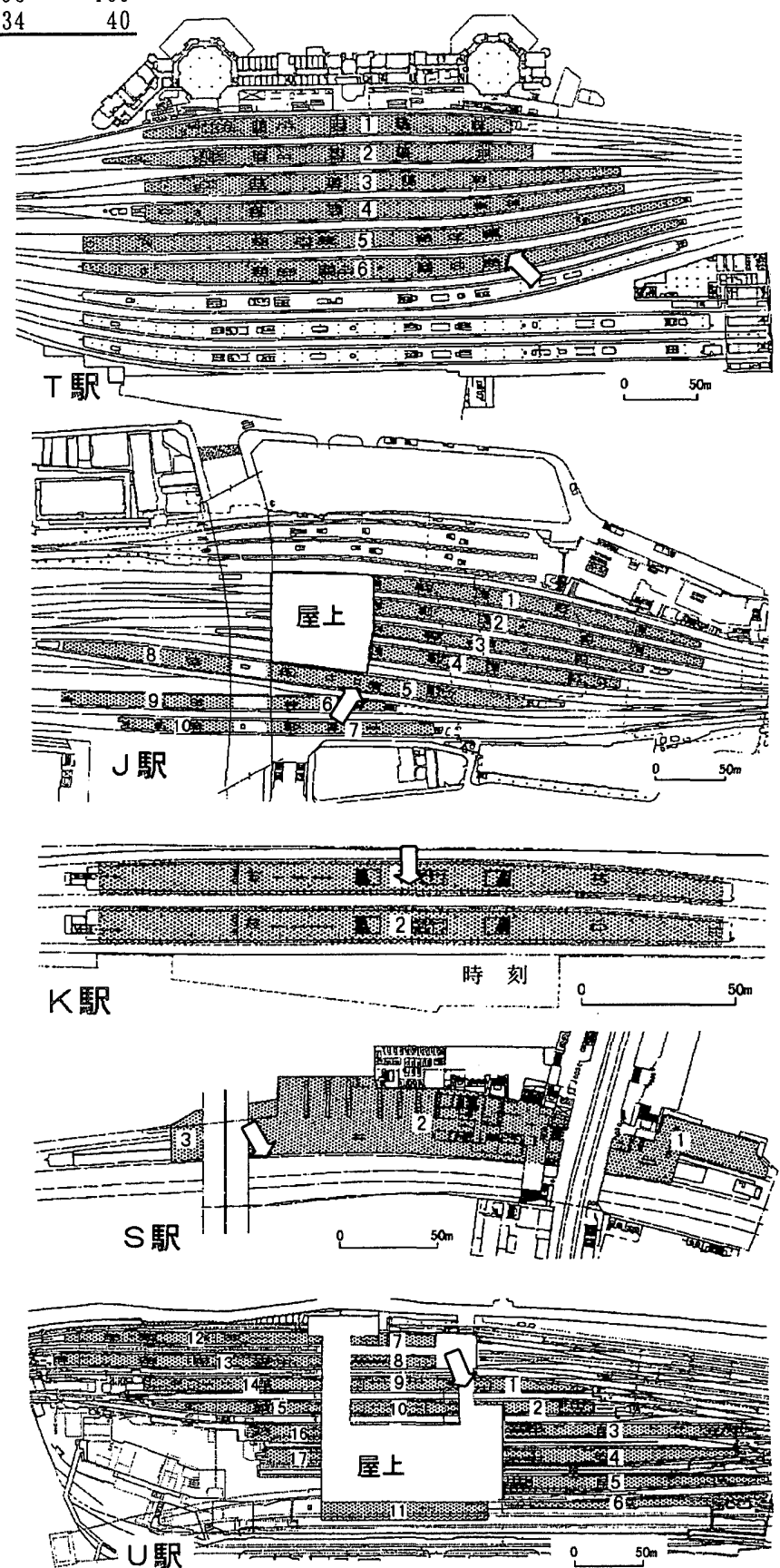

図-2 検討対象駅の屋根面 $\Rightarrow$ : 調查対象トイレ あり，上から，対象トイレに近い順に示している。J 駅の「5+8」 のような表記は，図-2 の同じ番号の屋根面を合わせてもとめたこと を示す。S 駅，U駅の「屋上/2」は，同じ屋根の下にトイレが 2 箅所 あり，それぞれが別個に雨水利用する場合を想定している。 
表- 6 各駅のホーム・建物屋根面積 $\left(\mathrm{m}^{2}\right)$

\begin{tabular}{|c|c|c|c|c|c|c|c|c|c|}
\hline 木- $4 \mathrm{~N}_{0}$ & T駅 & 木-4No & J駅 & 木- $4 \mathrm{~N}_{0}$ & K駅 & 木- $\angle N_{0}$ & $\begin{array}{l}\text { S 駅 } \\
\end{array}$ & 本一 $4 \mathrm{~N}_{0}$ & U駅 \\
\hline 5 & 4311 & 屋上 & 4260 & 1 & 1867 & 屋上/2 & 7293 & 屋上/2 & 4972 \\
\hline 6 & 4723 & 4 & 1589 & 2 & 2036 & 屋上/2 & 7293 & 屋上/2 & 4972 \\
\hline 4 & 3645 & $5+8$ & 3159 & - & - & - & - & $7+12$ & 2159 \\
\hline 3 & 3541 & 3 & 1395 & - & - & - & - & $8+13$ & 2327 \\
\hline 2 & 3247 & $6+9$ & 1698 & - & - & - & - & $1+9+14$ & 2635 \\
\hline 1 & 2968 & 2 & 2108 & - & - & - & - & $2+10+15$ & 2529 \\
\hline - & - & $7+10$ & 1568 & - & - & - & - & $3+16$ & 1966 \\
\hline - & - & 1 & 2351 & - & - & - & - & $4+17$ & 1946 \\
\hline- & - & - & - & - & - & - & - & $5+6+11$ & 4127 \\
\hline
\end{tabular}

表-6のトイレに最も近い屋根面を用いた場合の駅の収集雨水量算 定値を表- 7 に示す。収集雨水量は, 屋根面積に平均降水量を乗じて もとめた全量とした。各駅について屋根の一部を用いた簡易な算定 ではあるが, 最小の雨水収集面積でも, 年間で $2800 〜 11100 \mathrm{~m}^{3}$ の雨水 収集が可能と考えられ，駅は巨 大な雨水収集装置になり得るこ とがわかる。

\section{3 トイレの器具使用}

トイレの便器洗浄に雨水を用 いることを想定し，トイレ使用 水量を算定するために，トイレ 器具使用者数, 1 人あたり洗浄 回数および洗浄 1 回あたり使用 水量を設定する。

1) トイレの器具使用者数

既報6７)に示した「ラチ内ト イレ使用実態報告書 : 平成 5 年, 7 年」の冬季のデー夕を用いて, 5 駅の男子大便器, 男子小便器, 女子便器について 1 週間の使用 者数をもとめた。各駅, 各器具 における欠測値は，同様な利用 状況を示すと考えられる時間帯 の值で補完した。火，水，木の 3 日間が欠測の K, S, U駅に ついては, 平日(金, 月)の平均 值をこの 3 日間に適用した。

図-3にT駅，図-4にJ駅の 1 週間のトイレ器具使用者数を 示す。基本的に，使用者数は朝 に增加し，夜に減少する傾向は， 5 駅とも同じであるが, 個々の 器具の使用傾向は若干異なって いる。曜白別の傾向として, 土・ 日曜日と平日は区別でき，平日 に比べて土・日曜日では，男子 小便器使用者の夕方からの増加 が認められないこと, 女子便器 の使用者が全時間帯でやや多く なっていることがわかる。

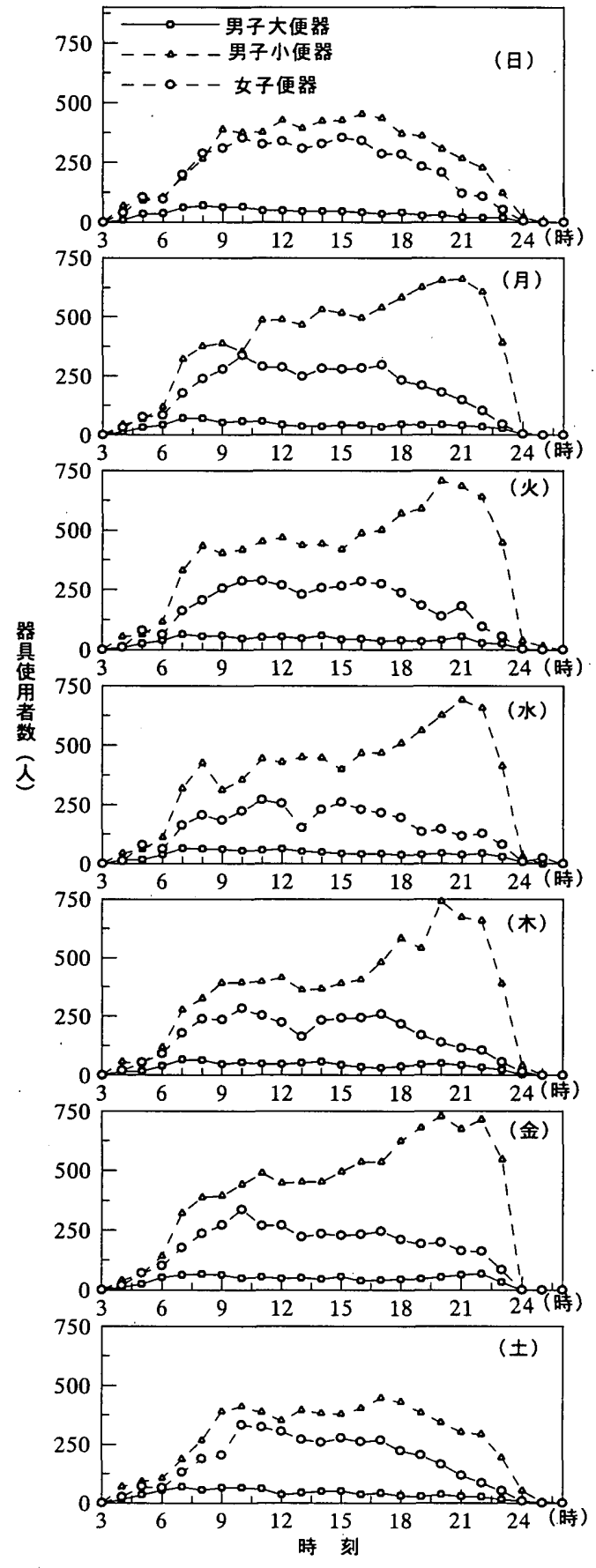

図-31週間のトイレ器具使用者数（T駅）
表- 75 駅の収集雨水量算定值

\begin{tabular}{lcccrc}
\hline \multicolumn{1}{c}{ 項目 } & T駅 & J 駅 & K駅 & S駅 & U駅 \\
\hline 適用建物㕠根面積 $\left(\mathrm{m}^{2}\right)$ & 4311 & 4260 & 1867 & 7293 & 4972 \\
平均降水量 $(\mathrm{mm} /$ 年) & 1529 & 1529 & 1536 & 1529 & 1529 \\
収集雨水量算定値 $\left(\mathrm{m}^{3} /\right.$ 年) & 6592 & 6514 & 2868 & 11151 & 7602 \\
\hline
\end{tabular}

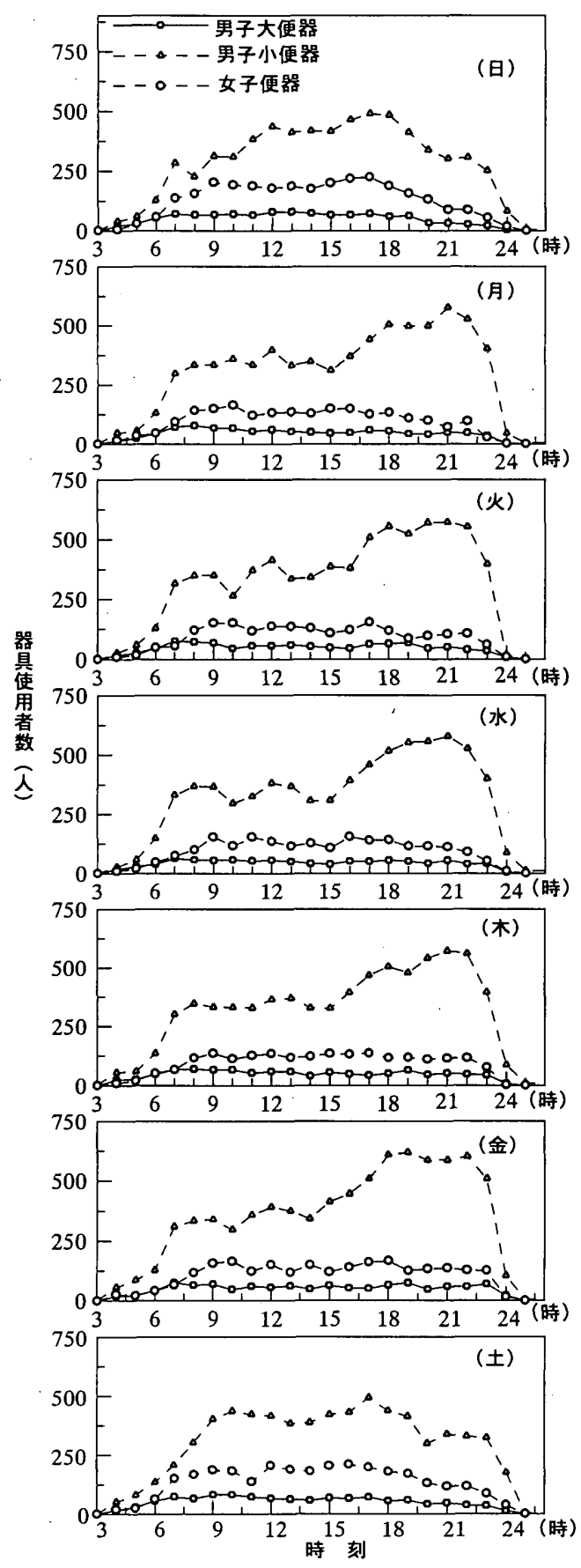

図-4 1週間のトイレ器具使用者数（ $\mathrm{J}$ 駅） 


\section{2) 器具別使用状況}

既報 ${ }^{6) 7)}$ に示した報告書の中で記述されている, トイレの器具占有 状況測定の際に, 並行して測定された男女の大便器ブース洗浄弁使 用状況の集計ファイルを用いて, 性別 - 駅別 - 器具別の占有時間, 洗浄回数の状況を明らかにし，使用水量算定の条件を決定する。集 計ファイルは, 各駅の対象トイレにおいて，男子大便器・女子便器 の占有状況調査時に記録された占有時間および洗浄弁使用記録から, 各ブースごとに 30 分単位で占有時間別・洗浄回数別にブース使用者 数を集計したものである。

(a) 洗浄弁使用回数

5 駅 4 日間(金土日月)の大便器占有時間の集計結果を，男女別に 図- 5 に示す。トイレ利用者の少ない深夜早朝は，集計から除いた。 図から，男子と女子とでは分布形が大きく異なり，男子の 5 分以上, 女子の 1 分以上 2 分未満の度数が多く, 男子は大便目的, 女子は小 便目的の便器使用が多いと判断できる。

図-6に示す洗浄回数の分布は, 男女とも同様な形状をしており， 1 回洗浄が $60 \sim 70 \%$ と大半を占め, 2 回以上は少ない。「女性の洗浄 回数は男性より多い」という傾向は若干みられる程度である。また 図より，洗浄弁を使用しない割合 (以降，無洗浄率と記す) は，男子 大便器が少ないU駅を除けば, 男子で約 10\%, 女子で約 $7 \%$ となり, 排便以外の目的で大便器ブースを使用するトイレ利用者が一定の割 合で存在することがわかる。男子のU駅の回数が 2 回, 3 回以上で 他の駅より多い。これは, U駅では, 小便器 18 個に対して大便器個 数 4 個と少ないため, 大便器の利用用途がほぼ大便に限られ, 小便 器の混雑時に大便器を小便用として使うケースがほとんど発生しな いことが原因と考えられる。なお，図一6のT駅は，男子トイレ洗浄 弁使用者の集計ファイルの一部に不備があり, 洗浄弁を使用しない ブース使用者の割合のみを示している。

5 駅 4 日間の集計值を用いた大便器ブース使用者の無洗浄率の時 間ごとの日変化を図-7 に示す。男子はU駅を除いて集計している。 図より，男女とも，曜日・時間帯で変動はあるものの，ほほ同じ範 囲で変化していることがわかる。図-7で示した 4 日間を平均した大 便器ブース使用者の無洗浄率を図-8に示す。これより, 無洗浄率の 平均的な経時変化の傾向を把握できる。女子は值の変動が小さい。
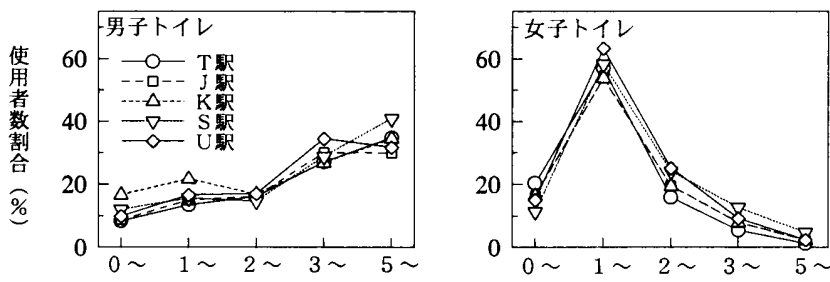

占有時間（分/人）

図-5大便器占有時間

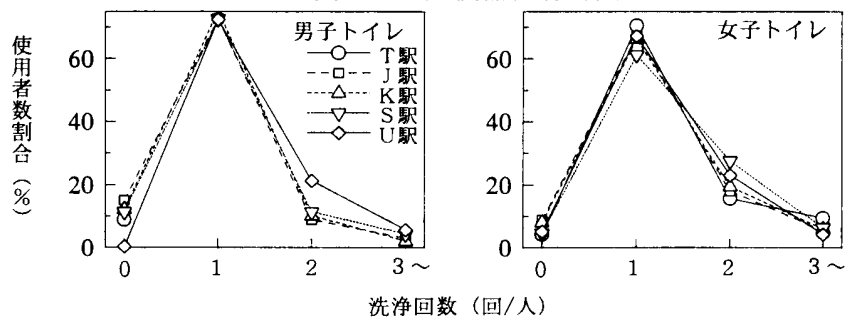

図-6 洗浄回数
男子は, 朝の大便器使用のピーク時である 8 時より增加する傾向が 認められ，夕方には $20 \%$ に達し変動の幅が大きい。この無洗浄率の 変化は, 男女とも, 既往の研究 ${ }^{7)}$ で筆者らが示したトイレ利用者数と 同様な 1 日の変化を示している。

そこで，4日間のトイレ利用者に対する無洗浄率の経時変化を図9 に示す。図より, 便器ブース使用者数が少ない女子の 6 時台を除 けば，男女とも，無洗浄率は時間帯の影響をそれほど受けずに，ほ ぼ同じ範囲で 1 日を推移していることがわかる。これら無洗浄率の 值は, トイレ利用者の一定の割合が, 排便以外の目的で大便器ブー スを使用していることを示しており，その割合は，男子と女子で， それぞれ平均 $1.2 \%$ と $4.0 \%$ となる。これより, トイレの使用水量算 定の際には，無洗浄率を設定し，洗浄弁の使用者のみを対象に洗浄 回数などを設定することが, より正確な算定結果を得るために必要 な手順といえる。
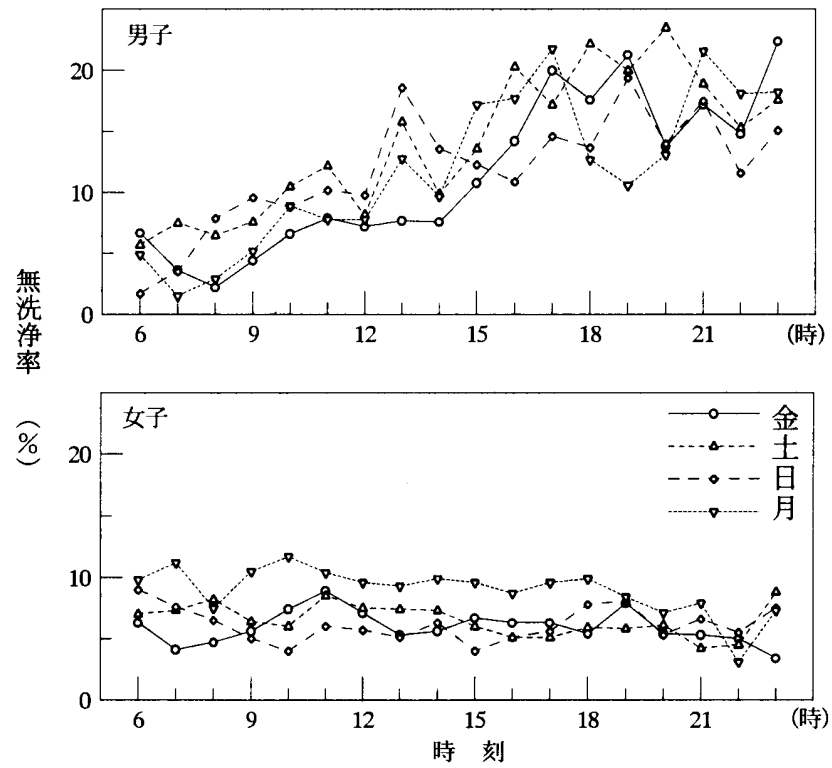

図-7 各曜日における大便器使用者の無洗浄率

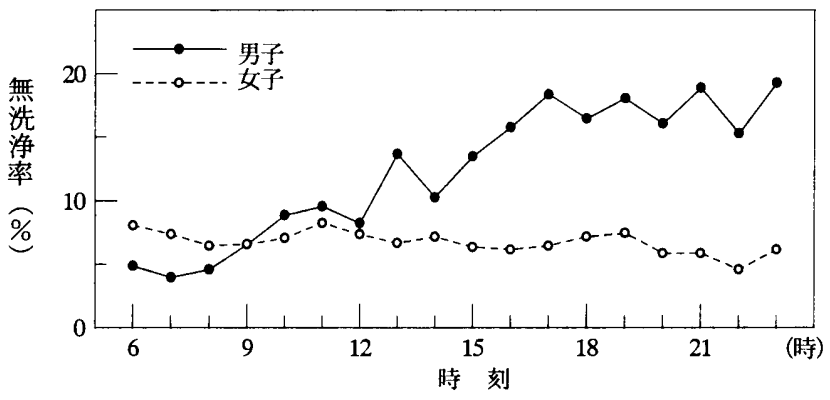

図-8 大便器使用者の日平均無洗浄率

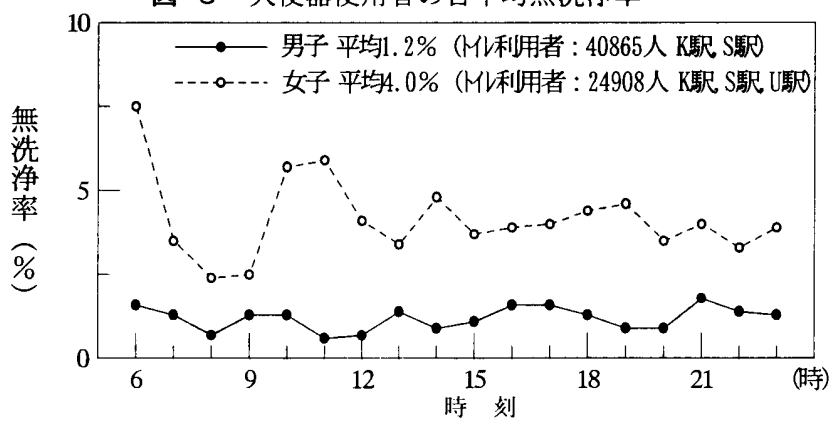

図-9 全トイレ利用者数に対する大便器使用者の無洗浄率 
表- 8 に 5 駅の洗浄回数の集計值を示す。值は, 無洗浄率を雨水利 用量算定の際に使用することを考え, 洗浄弁使用の有無別に集計し ている。U駅の男子を除けば，無洗浄率以外は男女とも各駅は同様 な值を示している。

以上の結果から，本論文では無洗浄率を考慮して，トイレの使用 水量を算定するが, 各駅の各時間帯の無洗浄率は, 図- 7 の值を用い ることとする。

（b）洗浄弁の使用水量

洗浄弁の使用状況測定時に一部の駅で測定された使用水量のデー 夕を用いて，洗浄弁の 1 回あたり使用水量を算定する。これらのデ 一夕は，節水型便器の性能評価を目的として，前述調查の際に測定 された節水型と通常型の便器使用水量および各便器における使用人 数である。表- 9 に通常型と節水型の大便器，表-10 に J 駅の通常型 小便器の測定值をそれぞれ示す。男子小便器は，1 人あたり 1 回洗浄 すると考えられるので, 表-10より小便器使用水量をもとめる。また 大便器の洗浄量は, 男子大便器では, 通常のK駅の使用水量を測定 時の洗浄回数で除してもとめ, 女子便器では, 男子通常型と男子節 水型の比を，女子節水型の使用水量に乗じてもとめた。

以上のように設定した使用水量の算定に供する值を表-11 に示す。

\section{4 トイレ使用水量の算定値}

上述の器具使用者数および設定値を用いて, 各駅, 各曜日, 各時 間帯について, 次の 4 要因を乗じてトイレ使用水量を算定した。
(1) 使用者数
(2) 洗浄率 : 1 - 無洗浄率
(3) 1 人あたり洗浄回数
(4) 1 回あたり使用水量

ここで算定された時間あたりトイレ使用水量が 1 年間毎週同じパ ターンを繰り返すものとしてシミュレーションに用いる。

各時間帯における值を 1 週間合計し，トイレ使用水量の平均値と してもとめた結果を図-10に示す。図より，トイレ使用水量は，6時 ごろから上昇し, 日中に目立ったピークや大きな落ち込みもなく，23 時ごろまで継続していることがわかる。

\section{5 雨水眝留槽容量}

シミュレーションに使用する 1 週間の 1 日の平均使用水量に相当 する容量の雨水貯留槽を 1 日槽として 5 日槽までを算定した。1日 の平均使用水量を表-12 の上段に示す。この 1 日槽の容量でさえ，既 設の駅舎トイレに適用するには，その大きさから，考慮を必要とす る。そこで，雨水貯留槽の容量を，最小に設定する0日槽も算定に 加えた。0日槽の条件では，算定の最小単位 1 時間の使用水量に相 当する容量の雨水貯留槽が存在するものとして算定する。具体的に は，0 日槽の容量は，各駅トイレの 1 週間の 1 時間あたり最大使用 水量であり，その容量は， $\mathrm{T}, \mathrm{J}, \mathrm{K}, \mathrm{S}, \mathrm{U}$ 駅でそれぞれ 14.5， $11.7,5.2,5.3,8.9 \mathrm{~m}^{3}$ となる。この条件では，算定中の 1 時間に雨 水の余剩が生じても，その余剩は０として算定を継続する。

\section{4. 雨水利用のシミュレーション}

シミュレーションは，1時間ごとの降水量を前述の 10 年分用いた 1 時間単位の算定となり, 各単位で雨水収集量から雨水利用量を除 いた雨水余㮃量を貯留槽容量へ送り保留する計算過程を繰り返す。 シミュレーションおよび算出評価指標は既報 ${ }^{8)}$ の内容に準じた。

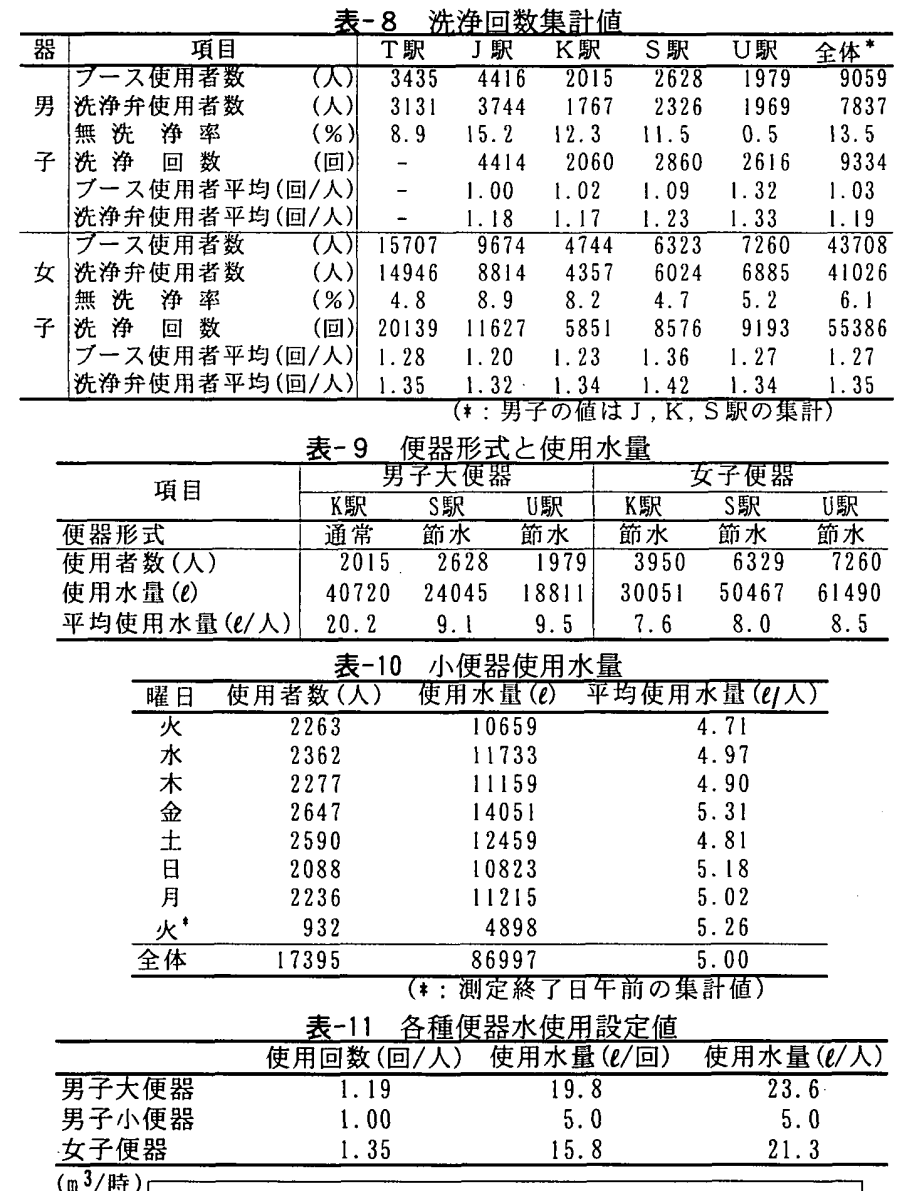

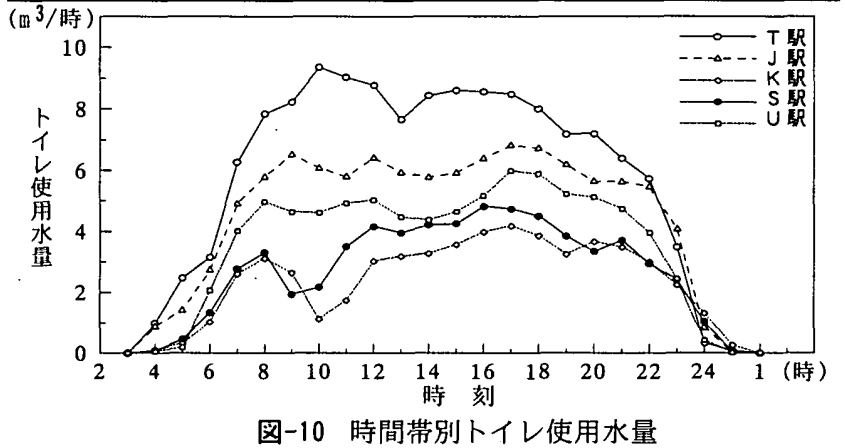

表-12 に算定結果の一部を示す。また, 駅舎における雨水利用シス テムを考える上で有効といえる指標として，雨水利用量と槽雨水利 用量を図-11，12 に示す。

表および図より，駅舎トイレにおける雨水利用システムは，前述 の雨水貯留槽 0 日槽においても，年間で $1000 \sim 2500 \mathrm{~m}^{3}$ の雨水利用が 可能であり，降雨時に水使用が少なく，眝めて使うことが基本とな る一般家庭のシステムとはかなり異なるといえる。しかし，これら の雨水利用量を雨水代替率でみるならば， $5.1 〜 6.5 \%$ とさく，雨 水を代替水源にできる量を確保することは難しいが，この值を節水 量として考えるならば有用である。また，通常のシステムで一般化 している雨水貯留槽を設けるなら，雨水収集面の大きな $\mathrm{S}$ 駅を除け ば，1 日分の使用水を貯める 1 日槽で雨水利用量を倍以上にする十分 な効果が得られる。しかし, さらに増加させても, 雨水収集面の増 加を伴わなければ，さらなる効果は期待できないことがわかる。槽 雨水利用量からは，1 日槽で $1 \mathrm{~m}^{3}$ あたり年間で $40 \sim 80 \mathrm{~m}^{3}$ の雨水が利用 可能であり，雨水貯留槽の経済的な効果は十分に期待できる。 
表-12 雨水利用シミュレーション算定結果

\begin{tabular}{|c|c|c|c|c|c|c|c|c|c|c|c|c|c|}
\hline 対象トイレ所在駅 & \multicolumn{3}{|c|}{ T駅 } & \multicolumn{3}{|c|}{$\mathrm{J}$ 駅 } & \multicolumn{2}{|c|}{ K駅 } & \multicolumn{2}{|c|}{ S 駅 } & \multicolumn{3}{|c|}{ U駅 } \\
\hline トイレ使用水量 $\left(\mathrm{m}^{3} /\right.$ 日) & \multicolumn{3}{|c|}{136.3} & \multicolumn{3}{|c|}{106.1} & \multicolumn{2}{|c|}{55.2} & \multicolumn{2}{|c|}{63.7} & \multicolumn{3}{|c|}{83.1} \\
\hline 雨水収集面 $\quad($ 市- L N N $)$ & 5 & 6 & 4 & 屋上 & 4 & $5+8$ & 1 & 2 & 屋上 $/ 2$ & 屋上/2 & 屋上 $/ 2$ & 屋上 $/ 2$ & $7+12$ \\
\hline \multicolumn{14}{|l|}{ 〈雨水貯留槽容量 0 日㮴〉! } \\
\hline 雨水利用量 $\quad\left(\mathrm{m}^{3} /\right.$ 年 $)$ & 2562 & 3238 & 3256 & 2197 & 2448 & 2527 & 1095 & 1378 & 1522 & 1522 & 1924 & 1981 & 1981 \\
\hline 雨水代替率 (節水率) $(\%)$ & 5.1 & 6.5 & 6.5 & 5.7 & 6.3 & 6.5 & 5.4 & 6.8 & 6.5 & 6.5 & 6.3 & 6.5 & 6.5 \\
\hline 雨水利用率 $\quad(\%)$ & 38.9 & 23.4 & 16.8 & 33.7 & 27.4 & 18.3 & 38.2 & 23.0 & 13.6 & 6.8 & 25.3 & 13.0 & 10.7 \\
\hline \multicolumn{14}{|l|}{ 〈雨水貯留槽容量 1 日槽〉 } \\
\hline 雨水利用肙 $\quad\left(\mathrm{m}^{3} /\right.$ 年 $)$ & 5647 & 8879 & 10220 & 5224 & 6322 & 7680 & 2412 & 3773 & 5108 & 6051 & 5143 & 6770 & 7160 \\
\hline 雨水代替率 (節水率) (\%) & 11.3 & 17.8 & 20.5 & 13.5 & 16.3 & 19.8 & 12.0 & 18.7 & 21.9 & 26.0 & 16.9 & 22.3 & 23.6 \\
\hline 雨水利用率 （\%) & 85.7 & 64.3 & 52.7 & 80.2 & 70.7 & 55.8 & 84.1 & 62.9 & 45.8 & 27.1 & 67.7 & 44.5 & 38.7 \\
\hline 橧雨水利用量 $\left(\mathrm{m}^{3} / \mathrm{m}^{3} \cdot\right.$ 年 $)$ & 41.4 & 65.1 & 75.0 & 49.3 & 59.6 & 72.4 & 43.7 & 68.4 & 80.2 & 95.0 & 61.9 & 81.5 & 86.2 \\
\hline
\end{tabular}

\section{5. 駅舎トイレの雨水利用システム}

シミュレーション算定結果からは, 使用水量が多大な駅舎トイレ では，雨水は全面的な代替水源とはなり得ないが，雨水利用量は大 きく, 節水効果は期待できる。また, 雨水貯留槽の設置効果は十分 あると考えられるが，1 日槽でさえ $55 \sim 136 \mathrm{~m}^{3}$ 必要であり，その巨大 な空間を，駅舎のどこに確保するかが問題といえる。現在の駅の構 造を考えるなら，プラットホームの下が雨水貯留槽の設置場所とし ては有望である。しかし, 高さが不十分で, 槽の清掃作業員が入る 空間が十分確保できない鱞念があるため検討を要する。このため, 設備投資に対する雨水確保の有効性を考えると, 駅舎トイレの雨水 利用には，1時間あたり最大使用水量分の容量でほとんど雨水を貯留 せずに雨水を利用するシステムで十分に効果があるといえる。

\section{6. 結語}

本論文では，器具あたり使用者数が多い，駅舎トイレを対象とし た雨水利用システムの導入計画を考え, 既往の調査値および公開さ れているデータを用い，東京都内 J R 5 駅について，降水量, 雨水 収集面, 雨水貯留槽, トイレ使用水量を設定し, シミュレーション により雨水利用システムの有用性を検討した。

その結果, 雨水貯留槽設置の効果は認められるが, トイレ使用水 量が 1 日あたり 55〜136m ${ }^{3}$ と大きく，1日槽でもそのスペースを駅構 内に新たに設置することは困難と考えられ，設備投資に対する雨水 確保の有効性を考えると，駅舎トイレでは，1時間あたり最大使用水 量分の容量でほとんど雨水を貯留せずに雨水を利用するシステムで 十分に効果があることを示した。

\section{謝辞}

$\mathrm{JR}$ 駅の雨水収集面の検刢に際しこ協力を戴いた，脷JRE 設計 仲川ゆり氏お よび研究資料の入手にこ配虚戴いた懒木村技研 常務 木村友映氏に，記して 謝意を表する。

参考文献

1) 越川康夫, 村川三郎: 収集雨水污濁防止を目的とした初期雨水排除奮の検討 雨水の水質性状と有効利用に関する研究 そのI -, 日本建築学会計画系論 文報告集, No. 350, pp. 8-17,1985.4

2）越川康夫:雨水利用システムにおける規模算定法, 建勧設備と配管工事, No $334, V_{0} 1.26, N_{0} .6,1988$

3）越川康夫，村川三郎，西田勝:雨水利用システムにおける雨水利用効率と都 市型洪水防止効果の検討, 一福岡市の戸建て住宅を事例として -, 日本建築 学会計画系論文報告集, Vol. 452, pp. 37-45, 1993.10

4)レインドロップス研究会編:やってみよう雨水利用, 北斗出版, 1994

5)村川三郎, 森田大, 三翰信哉, 越川康夫:沖綶離島における住宅の水利用睘境 に関する研究, 一雨水利用を中心として一, 日本建築学会計画系論文報告集,

No. 368 , pp. 52-61, 1986. 10

6)村川三郎, 坂上新助, 越川康夫, 仲川ゆり, 高津靖夫 : 駅舎における乘降者数 とトイレ利用数の换討,駅舎トイレの器具数算定法に関する研究 その 1, 日
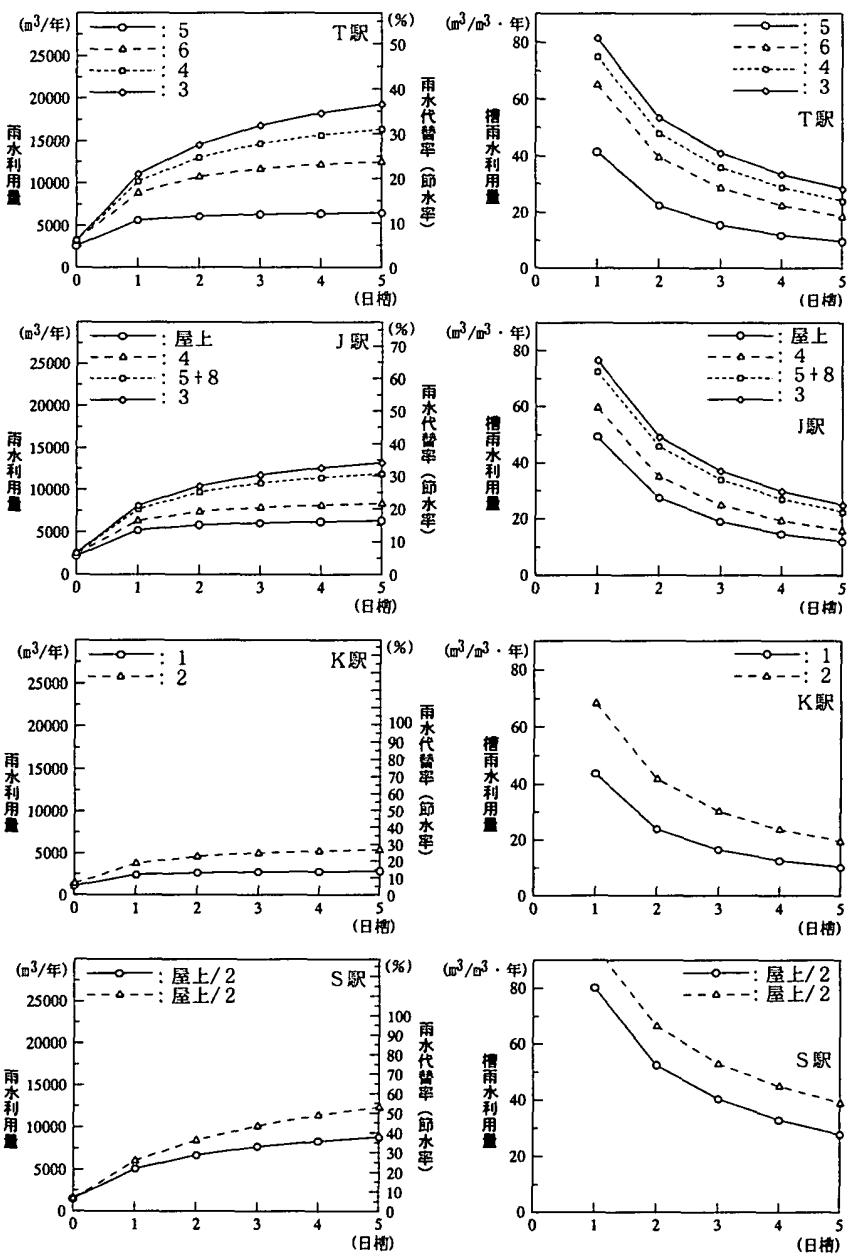

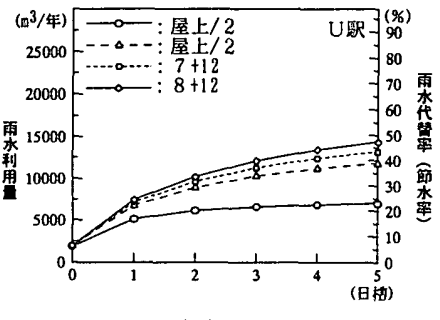

雨水眝留槽容量

図-11 雨水利用量

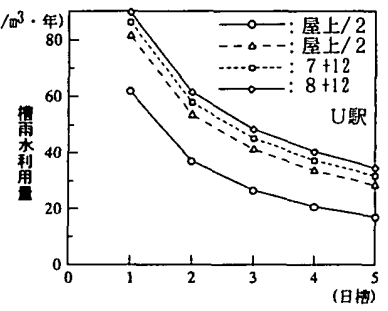

雨水貯留播容量
図-12 槽雨水利用量

本建築学会計画系論文報告集, No. 522, pp.91-96,1999.8

7）越川康夫, 村川三郎, 坂上萑助，仲川ゆり，高津靖夫：駅舎トイレにおける 器具使用とその特性の検討, 駅舎トイレの器具数算定法に関する研究 その 2 ，日本建築学会計画系論文報告集, No. 526, pp. 59-65, 2000.2

8）にに同じ 